cleanliness in the form of live potential dirt that is unpleasant to contemplate, and is not without its dangers. The results of the examination revealed a state of affairs which calls for remedial action.

The usual exhibition of sanitary apparatus and appliances was held in association with the congress, and a new feature, which certainly met with an encouraging amount of success, was the delivery, each evening, of free popular lectures upon different items of general hygiene.

\section{INDIAN IRRIGATION AND ITS RELATION TO FAMINES.}

$\mathrm{I}$ the summer of I9or the Governor-General of India in Council decided on the formation of a special commission to report on the irrigation of India as a protection against famine.

The commissioners appointed were Sir T. Higham, M.I.C.E., Inspector-General of Irrigation; the Hon. Denzil C. J. Ibbetson, Chief Commissioner of the Central Provinces; the Hon. J. W. P. Muir Mackenzie, Secretary to the Government of Bombay; Diwan Bahadur Mudaliar, member of the Legislative Council of Madras; with Sir Colin Scott Moncrieff as president, and Mr. W. B. Gordon, M.I.C.E., as secretary. Their first meeting was held at Lahore on October 29, 1901. Two years were spent in inspecting all the principal irrigation works, and their report was presented to Parliament a short time ago in the form of a Blue-book.

About the same time the Department of the Interior United States Geological Survey sent Mr. Herbert M. Wilson, one of their staff, to India to investigate the method of irrigation as carried out there, and to obtain such information as might be of use to the department charged with the irrigation works in the western States and the reclamation service of the American Geological Survey.

His report, entitled "Irrigation in India," 2 was published in 1903. Largely as the result of the renewed activity in irrigation in America, the first edition of the report was soon exhausted, and a second edition revised up to date has been issued.

India stands preeminent in the gigantic engineering undertakings carried out for irrigation purposes. No other country has so vast and so fertile an expanse of territory with such convenient slopes for the construction of canals, and at the same time such an abundant though varied water supply.

The main factors determining the use and value of irrigation are the rainfall, the character of the soil, and the class of crop best suited to the special conditions prevailing.

In India the zone of heaviest rainfall lies along the western coast of the main peninsula, where the monsoon striking the western Ghats precipitates on their outer slopes an average annual rainfall of 100 to 250 inches. On the outer ranges of the Himalayas the annual rainfall amounts to $46 \mathrm{r}$ inches. Over the greater part of India, however, the rainfall is below 40 inches. In the extreme south of the peninsula it is scanty and precarious, and in some of the States of the north-west the average annual fall is as low as 5 inches. Where the annual rainfall is below from Io to 12 inches cultivation is practically impossible without irrigation. Where it is abundant and exceeds yo inches the chance of the failure of the crops may be regarded as so remote as to make irrigation unnecessary. Between these two extremes lies a vast tract of nearly a million square miles of which, in the absence of irrigation, no part can be deemed absolutely secure against the uncertainties of the season and the scourge of famine.

On the irrigated lands two crops can be taken in the year, one of which is sown in the early spring and gathered in the autumn, and the other sown in the autumn and gathered in the spring. The summer crop depends little' on irrigation for its maturing, as this is growing during the monsoon or rainy season. The autumn crop consists of

1 Report of the Indian Irrigation Commission, 1901-3. Part i. General. (Eyre and Spottiswoode). Price 1s. $4 d$.

" "Irrigation in India." By Herbert M. Wilson. (Washington: Government Printing Office.) millet, pulses and rice, and the spring crop of wheat, barley, linseed and grain. The crops mainly dependent on irrigation to ensure a full return are wheat, barley, sugar cane, garden crops, and cotton where it grows on the black soil. The area under wheat covers more than 16 million acres, and that on which cotton is grown $8 \frac{1}{3}$ million acres. Rice is an extensively cultivated crop, but is principally limited to the delta lands of the Orissa, Godaveri and Bengal; 8o per cent. of the crops raised in such regions are rice. Millet and oil seeds also are important crops. All kinds of vegetables and fruit are produced, these being the chief food of the natives. Jute is very extensively grown, the largest imports to this country coming from India. Indigo is also largely grown by the natives, and poppies for the production of opium. Tobacco and coffee are only grown in small quantities. Tea is extensively grown in Assam, where it is indigenous, and also in Darjeeling.

Irrigation has been practised in India from time immemorial. Many of the large tanks or storage reservoirs date back to the eighth and ninth centuries. The Grand Anicut in Madras is supposed to have been made in the second century. A canal on the banks of the Jumna made by the former rulers was restored in 1814 , and the experience gained in this work led to the construction of the great Ganges Canal, a work which in magnitude and boldness has not been surpassed by any irrigation work.

The total length of the Government irrigation canals, including branches, is 36,000 miles, and they can discharge more than 100,000 cubic feet of water a second, and irrigate annually 19 million acres. There are also 7000 miles of minor protection works and storage reservoirs with a capacity of 25,000 million cubic feet.

The total area in India irrigated is estimated at 44 million acres, of which $4^{2}$ per cent. is supplied with water from State works, $15^{\frac{1}{2}}$ millions being from canals, and 3 millions from reservoirs. Of the private works, covering $25 \frac{1}{2}$ million acres, 2.8 per cent. is from canals, 11.8 from tanks, 292 from wells, and 14 from other sources.

The capital outlay on the thirty-nine canals and major works up to the end of rgor was more than $36 \frac{1}{2}$ millions of pounds (counting a lakh of rupees as equal to ro,oool.) The annual revenue after paying all working expenses was 7.1 per cent. The works in the Punjab yield a net revenue of $10 \frac{1}{2}$ per cent.; those in Bombay and Bengal do not earn enough revenue to cover interest charges on capital outlay.

The value of the crops irrigated in a single year is about equal to the whole capital cost of the works, and in time of famine the produce of the irrigated area being largely available for transport to distressed districts becomes an important item in the general food supply of the country. The irrigation works have also been largely instrumental in relieving congested districts. Some of the great canals in the North-West Provinces and the Punjab were undertaken in districts that were sparsely inhabited; within ten years from their construction the country became fully populated.

With regard to the value of irrigation works in mitigating the horrors and cost of famines, in the Sholapur district where four famines have occurred since 1846 , and where the cost to the State of the last two famines in 1896 and 1899 was equal to $1,150,000 l$, the estimated loss is reckoned at $50,000 \mathrm{l}$, a year, which, capitalised at 4 per cent., amounts to $1 \frac{1}{4}$ millions of pounds as the limit of unproductive expenditure that might be incurred for the sake of avoiding the future cost of famine relief for this district alone. During the terrible famine of 1876 , for which a large relief fund was raised in this country $5^{\frac{1}{2}}$ million of lives were lost, although the Indian Government expended II millions of pounds in relief.

Many of the great works already undertaken have been the direct outcome of famines. The great famine of 1837 in Bengal led to the project of the Ganges Canal, which has now 5500 miles of main canal and branches; the famine which desolated Orissa and the north of India in 1864 , when a million of the inhabitants lost their lives by starvation, notwithstanding the expenditure of upwards of $6 \frac{1}{4}$ millions of pounds in combating the famine, and also more than 3 millions in works of irrigation, resulted in the policy since adopted of systematically carrying out extraordinary public works and expending half a million a year in developing

NO. I 8 I 5 , VOI. 70] 
irrigation for the purpose of preventing the recurrence of these terrible disasters.

As the result of its investigation, the commission found that in the several districts it visited a programme of works had been prepared for work in such proportion of the population as is likely to be affected by famine, and that it was claimed that most of these works would be of a useful character; but the commissioners were of opinion that the degree of utility likely to be attained must for the present be regarded as uncertain, many of the works having been hurriedly selected. In addition to irrigation, the works included roads and railways.

The commissioners also recommended a very extensive programme of protective irrigation works to be constructed as rapidly as may be practicable in the tracts that are most likely to suffer from famine. They also endorse the recommendation of the Famine Commission of 1901 , that greater reliance should be placed in future on village works as a means of employing relief labour than has been the practice in recent famines. They, however, advise the use of caution, and express the opinion that no relief labour can be more useless than that expended on works which, however useful if eventually completed, will probably remain as a famine folly, incomplete for ever.

They strongly recommend that a central board should be constituted, and invested with the responsibility of regularly watching and reporting progress as to works set out in the programme laid down, and of guarding against material deviations from the working plans of each province being made without the express sanction of the Government.

For the prosecution of their programme of new State irrigation works, it is pointed out that a large and permanent increase will have to be made in the strength of the engineering establishment.

The general conclusion arrived at is that there is a wide but not unlimited field in which the engineers and civil officers can work together for the protection of the country from famine, partly by the construction of new State irrigation works, and partly by encouraging and stimulating the extension of irrigation by means of private works. Both methods will involve heavy expenditure on the part of the State, upon which there may not be anv direct return, although it may be justified by the value of the protection afforded. While the whole of India can never be protected from famine by irrigation alone, yet much can be done to restrict the area and to mitigate the intensity of famine. Any enduring success of works carried out will depend no less on their effect in evolving a spirit of self-help and thrift among the people than in their efficiency in securing crops from drought.

Mr. Wilson's report is of considerable value to engineers engaged in irrigation works, as it contains a great deal of information relating to constructive works, such as weirs, sluices, and dams, and also descriptions, accompanied by illustrations, of many of the principal irrigation works carried out in India.

\section{UNIVERSITY AND EDUCATIONAL} INTELLIGENCE.

OXFORD.-The following re-appointments for three years have been made:-Dr. A. J. Herbertson, to be lecturer in regional geography and curator of the School of Geography; Dr. G. B. Grundy, to be lecturer on ancient geography; Mr. C. R. Beazley, to be lecturer on the history of geography.

Dr. Reginald Buller, lecturer on botany in the University of Birmingham, has been appointed professor of botany in the University of Manitoba.

THE Salters' fellowship of the Pharmaceutical Society has again been conferred on Mr. J. Stuart Hills, who since October, 1903, has devoted himself entirely to research work.

Dr. A. W. Crosslex, lecturer in chemistry at St. Thomas's Hospital Medical School, has been appointed to succeed Prof. W. P. Wynne, F.R.S., in the chair of chemistry in the School of Pharmacy of the Pharmaceutical Society of Great Britain, and the following demonstrators have also been appointed in the latter school:-Mr. F. G. C. Walker in chemistry, Mr. J. T. Cart in pharmaceutics; and Mr. T. G. Hill in botany.

$$
\text { NO. I } 8 \text { [ } 5 \text {, vOL. 70] }
$$

THE Drapers' Company has discharged the debt of University College, London, to the bankers to the amount of 30,0ool. The treasurer has received from Messrs. Wernher, Beit and Co. their cheque for $10,000 l$, promised to promote the incorporation of the college in the university. For the completion of the incorporation scheme, there yet remains the sum of $18,000 l$. to be raised. Prof. Oliver has been re-appointed to the Quain chair of botany. Dr. F. J. Poynton has been appointed sub-dean of the faculty of medicine in succession to Prof. G. D. Thane, resigned. The session 1904-5 will begin, in the faculties of arts and laws and of science, on Tuesday, October 4, and in the faculty of medicine on Monday, October 3. The introductory lecture will be given by Prof. J. Normań Collie, F.R.S., on October 3 , at 4 o'clock.

\section{SOCIETIES AND ACADEMIES. LONDON.}

Royal Society, June 2.- "The Advancing Front of the Train of Waves Emitted by a Theoretical Hertzian Oscillator." By A. E. H. Love, F.R.S., Sedleian Professor of Natural Philosophy in the University of Oxford.

The waves emitted by Hertz's oscillator have been identified with those due to a vibrating electric doublet. The field due to a variable doublet is expressed by equations of the form

$$
\left.\begin{array}{l}
(\mathrm{X}, \mathrm{Y}, \mathrm{Z})=\left(\frac{\partial^{2}}{\partial x \partial z}, \frac{\partial^{2}}{\partial y \partial z},-\frac{\partial^{2}}{\partial x^{2}}-\frac{\partial^{2}}{\partial y^{2}}\right) \frac{\psi(\mathrm{c} t-r)}{r} \\
(\alpha, \beta, \gamma)=\frac{1}{\mathrm{C}}\left(\frac{\partial^{2}}{\partial y \partial t},-\frac{\partial^{2}}{\partial x \partial t}, 0\right) \frac{\psi(\mathrm{c} t-r)}{r}
\end{array}\right\}
$$

in which $\mathrm{c}$ is the velocity of radiation, and $\psi(\mathrm{c} t)$ is the moment of the doublet at time $t$. When there is damping $\psi$ has the form

$$
\psi=\mathrm{A} e^{-\frac{v}{\lambda}(c t-r)} \sin \frac{2 \pi}{\lambda}(\mathrm{c} t-r+\epsilon),
$$

where $\lambda$ is the wave-length, A a constant depending upon the amplitude of the vibrations, $\epsilon$ a constant expressing the phase, and $\nu$ a constant expressing the damping. According to the experiments of Bjerknes, $\nu$ may be taken to be about 0.4 when the wave-length $\lambda$ is about io $\mathrm{m}$. The constant $\epsilon$ is determined by the conditions which hold at the front of the waves $(r=c t)$. The field outside

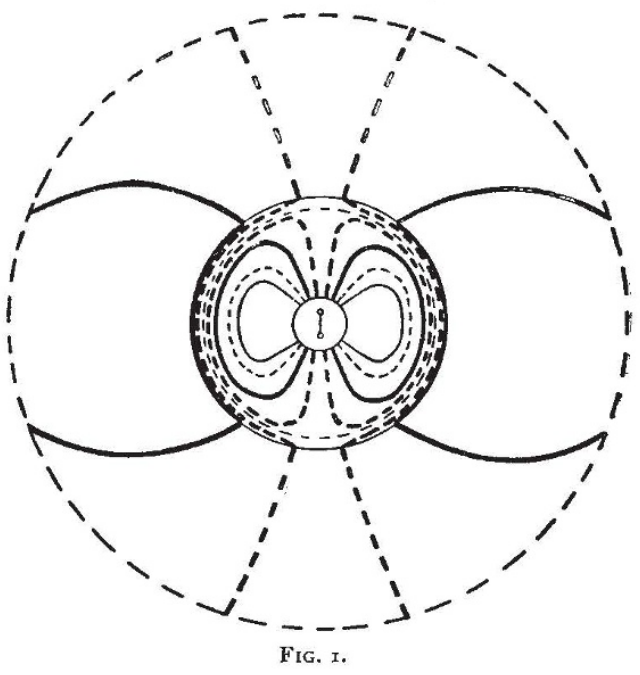

this surface is that which is established at the instant when the vibrations begin. At this instant the brass balls of the oscillator are so highly charged that the electric strength of the air between them gives way. The initial field is that due to the charges at this instant, so that it can most appropriately be represented as the electrostatic field of a fixed doublet.

.It is shown that the moment of the initial doublet is the maximum moment of the vibrating doublet, and that $\epsilon$ is given by $\tan \frac{2 \pi \epsilon}{\lambda}=\frac{2 \pi}{\nu}$. 